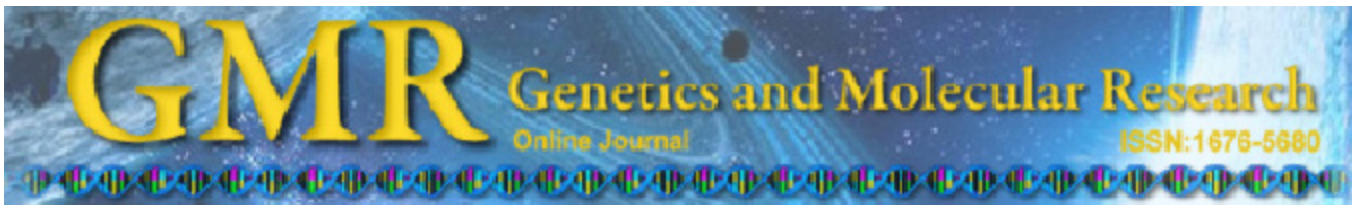

\title{
Is there a relationship between polyploidy and stressful environments? A case study of inselbergs in northeastern Brazil
}

\author{
S.R. Pitrez, L.A. Andrade, F.N.M. Assis and L.P. Felix \\ Laboratório de Citogenética Vegetal, Departamento de Fitotecnia, \\ Centro de Ciências Agrárias, Universidade Federal da Paraíba, Areia, \\ PB, Brasil \\ Corresponding author: F.N.M. Assis \\ E-mail: nolletmedeiros@yahoo.com.br
}

Genet. Mol. Res. 13 (4): 8353-8366 (2014)

Received August 6, 2013

Accepted January 10, 2014

Published October 20, 2014

DOI http://dx.doi.org/10.4238/2014.October.20.11

\begin{abstract}
The aim of this study was to examine the hypothesis that plants with higher ploidy levels are selected by environments under more extremely stressful conditions than the same (or closely related) species from less rigorous terrestrial or epiphytic habitats. Therefore, we analyzed the chromosome numbers of 26 species belonging to 21 genera and 13 families of angiosperms that were collected on 4 inselbergs in Paraiba State, northeastern Brazil. In addition, 13 rupicolous species that grow in the study area, whose chromosome numbers were previously determined, were included in our analysis. Plant chromosome numbers varied between $2 \mathrm{n}=12$ in Callisia filiformis (Commelinaceae) to $2 \mathrm{n}=$ ca. 240 in Epidendrum cinnabarinum (Orchidaceae). The data as a whole do not support the hypothesis that inselberg species have greater levels of ploidy than terrestrial or epiphytic populations of the same or closely related
\end{abstract}


species because these rupicolous species demonstrate chromosomal evolution patterns that are independent of the stressful environments of inselberg formations.

Key words: Chromosome number variation; Karyotype; Cytogenetics; Cytotypes; Chromosome evolution; Whole-genome duplication

\section{INTRODUCTION}

Karyotype analyses are an important tool for evolutionary studies and can reveal different strategies of chromosomal evolution (Guerra, 2012). In these analyses, chromosome number is one of the most used, reliable, and practical features for characterizing a large number of plant species. Different from morphological or biochemical characteristics, which depend on the expression of some genes, chromosomal characteristics have the great advantage that the karyotype is nothing less than the genome itself and that its phenotype at metaphase does not depend on gene expression, environmental conditions, age, and developmental phase (Guerra, 2012).

An important and particularly widespread feature in the phylogeny of flowering plants is polyploidy (whole-genome duplication), which is considered to be the major driving force behind the chromosome number variation in angiosperms. This mechanism is very important for speciation, and it has profound impacts on biodiversity dynamics and ecosystem functioning (Ainouche and Jenczewski, 2010). Molecular analyses suggest that the genomes of $90 \%$ extant angiosperms retain evidence of one or more ancient genome-wide duplications (Leitch and Leitch, 2008). Despite the occurrence of polyploidy in angiosperms, its implications to evolution have long been debated (Leitch and Leitch, 2008; McIntyre, 2012). In the face of this constant occurrence, some questions arise about the advantages of polyploidy, such as greater abiotic and biotic tolerances (McIntyre, 2012). In orchids, the occurrence of terrestrial or rupicolous growth habitats among species belonging to typically epiphytic genera is often correlated with polyploidy. Many rupicolous species of the genus Cattleya, for example, are tetraploids, while the epiphytic species are exclusively diploids. Other genera of orchids, such as Oncidium and Epidendrum (Felix and Guerra, 2010), are also polyploid when rupicolous, suggesting that the occurrence of these cytotypes is related in some way to the occupation of these habitats.

Many rupicolous species are found in inselbergs (from German insel: island and berg: mountain), that are rock outcrops, which are frequently huge, giga-year-old monoliths that mainly consist of Precambrian granites or gneisses and are defined as remnants of erosion processes within a plain landscape (Sarthou et al., 2010). This single model of environment supports ecologically isolated vegetations that are quite distinct from those of the surrounding area because of the extreme edaphic and climatic conditions that are encountered on these rock faces (Parmentier et al., 2005). Species that inhabit inselbergs are extremely well adapted to water stress, high solar radiation, high temperatures, and high levels of evapotranspiration because of evolutionary sympatric differentiation in relation to the species around them (Parmentier et al., 2005). Inselbergs host flora that originated from ancestral plants and were probably derived from more stable terrestrial or epiphytic environments, resulting in a spatial pattern of species that was promoted by stochastic processes, 
such as dispersal and demographic drift, which can lead to colonization and local extinction, respectively (Parmentier et al., 2005).

The notion of the adaptive value of polyploidy has its origin in the observation that highly polymorphic species form polyploid complexes adapted to extreme habitats with strong environmental pressure, such as Galium anisophyllum (alpine areas) and Cruciata coronata (dry environments) (Ehrendorfer, 1970). The increased adaptability of polyploids in relation to their diploid progenitors has been confirmed in artificial neo-polyploids, where the reduction in both pollen and seed fertility in the F1 generation is rapidly recovered in later generations (Ramsey and Schemske, 2002). Positive genetic combinations derived from polyploid events could result in an increased capacity of these polyploids to colonize habitats that were previously unusable by their diploid progenitors (Soltis et al., 2004). Most orchid species are epiphytic with terrestrial ancestors (Benzing, 1990), and most of these epiphytes are hexaploids (Felix and Guerra, 2005). Some groups within the family Orchidaceae that grow on inselbergs have a distinctly higher ploidy level than related epiphytic species (Felix and Guerra, 2010). To test the hypothesis that plants growing under stressful conditions tend to have higher ploidy levels, we examined the chromosome number of 26 species belonging to 13 families of angiosperms that occur on various inselbergs in northeastern Brazil. These species were among the most representative of this flora in a previous floristic survey of inselbergs in this region (Pitrez, 2006). In order to increase the sample size, we included an additional 13 inselberg species with previous chromosomal reports.

\section{MATERIAL AND METHODS}

\section{Plant material}

All the species examined were collected on inselbergs in Paraíba State, Brazil, especially on 4 peaks in the municipalities of Esperança, Fagundes, Pocinhos, and Serraria. In order to identify the best-represented groups on these inselbergs, floristic and phytosociological studies were first undertaken (Pitrez, 2006). In addition to the species collected on these 4 outcrops, 2 species (Rauwolfia ligustrina and Cissus sulcicaulis) were collected from inselbergs in the municipalities of Araruna and Barra de Santa Rosa (also in Paraíba), respectively. Material collected was cultivated in the experimental garden at the Departamento de Fitotecnia of Universidade Federal da Paraíba before cytogenetic examination. Reference material was deposited in the Jayme Coelho de Moraes Herbarium (EAN) of Centro de Ciências Agrárias of Universidade Federal da Paraíba.

\section{Slide preparation}

Root tips were pre-treated with 0.002 M 8-hydroxyquinoline Sigma-Aldrich (Saint Louis, MO, USA) for 4 to $24 \mathrm{~h}$ at $4^{\circ} \mathrm{C}$, fixed in Carnoy's solution (3:1 absolute ethanol:acetic acid, v/v - Merck KGaA, Darmstadt, Germany) for a period of 3 to $24 \mathrm{~h}$ at room temperature, and stored at $-20^{\circ} \mathrm{C}$ for later analysis. For slide preparation, root tips and flower buds were washed in distilled water to remove the fixative, hydrolyzed in $5 \mathrm{~N}$ $\mathrm{HCl}$ (Merck $\mathrm{KGaA}$ ) for $20 \mathrm{~min}$ at $20^{\circ} \mathrm{C}$, and washed in distilled water.

Squash preparations were made in a drop of $45 \%$ acetic acid (Merck KGaA). After 
the cover slips were removed by immersion in liquid nitrogen, they were allowed to dry at room temperature, stained with $2 \%$ Giemsa (Merck KGaA) for 10 min, and mounted in Entellan (Merck KGaA). Interphase nuclei and patterns of prophase condensation were classified and photographed using an light microscope BX41 Olympus (Tokyo, Japan) fitted with an Olympus D-540 digital camera.

\section{RESULTS}

Twenty-six species belonging to 21 genera and 13 families of angiosperms were collected on the inselbergs and studied. Eighteen of these species (Alstroemeria longistaminea, Hippeastrum stylosum, Mandevilla tenuifolia, Rauwolfia ligustrina, Aristolochia birostris, Eupatorium ballotaefolium, Melocactus bahiensis, Melocactus ernestii, Pilosocereus pachycladus, Clusia nemorosa, Tradescantia ambigua, Euphorbia comosa, Stillingia trapezoidea, Paliavana tenuiflora, Sinningia nordestina, Phyllanthus clausseni, and Cissus sulcicaulis) were karyotyped for the first time. Table 1 lists the species that were examined, their chromosome numbers, collection locations, and data concerning other inselberg species known to occur in the survey area that were previously examined in published (or unpublished) studies. Most species that were examined demonstrated semi-reticulated interphase nuclei with lightly stained chromatin filaments, irregularly shaped chromocenters, and chromosomes with proximal condensation patterns. Only Alstroemeria sp, Hippeastrum stylosum, and Tradescantia ambigua had reticulated interphase nuclei, uniformly distributed chromatin, and a distinctly continuous prophase condensation pattern. The chromosomal counts of the other 12 species were confirmed by at least one of the previously published reports. The only exception was Eupatorium ballotaefolium.

Alstroemeria longistaminea, of the family Alstroemeriaceae (Figure 1A), with $2 \mathrm{n}=$ 16, demonstrated a bimodal karyotype with 2 metacentric pairs. The largest pair was $19.3 \mu \mathrm{m}$ long and the shortest was $7.3 \mu \mathrm{m}$. The other chromosomes were acrocentric and gradually diminishing in size, from 9.3 to $6.1 \mu \mathrm{m}$, with a terminal satellite on the short arm of one of the largest acrocentric chromosomes.

Hippeastrum stylosum (Amaryllidaceae) showed $2 \mathrm{n}=22$, and chromosomes ranged from 4.6 to $11.3 \mu \mathrm{m}$ (Figure 1B). The karyotype of this species is formed by 4 pairs of small metacentric chromosomes and 7 large submetacentric and acrocentric pairs.

Two species were analyzed from the family Apocynaceae: Mandevilla tenuifolia (Figure 1C), with $2 \mathrm{n}=20$, and Rauwolfia ligustrina, with $2 \mathrm{n}=22$ (Figure 1D). The former species has larger chromosomes $(1.0$ to $1.7 \mu \mathrm{m})$ than the latter $(0.3$ to $1.3 \mu \mathrm{m})$. In both species, the chromosome morphology was difficult to define. The present count of $2 \mathrm{n}=20$ for Mandevilla tenuifolia is the first for the genus.

Aristolochia birostris (Aristolochiaceae) demonstrated a chromosome number of $2 \mathrm{n}$ $=14$ (Figure 1E), with metacentric and submetacentric chromosomes that were 1.0 to 1.7 $\mu \mathrm{m}$.

Eupatorium ballotaefolium (Asteraceae) has $2 \mathrm{n}=20$ chromosomes (Figure $1 \mathrm{~F}$ ). This species demonstrated a symmetrical karyotype that was formed by 1 acrocentric chromosomal pair that was 1.2 to $2.1 \mu \mathrm{m}$ long (the other pairs were submetacentric to metacentric), a pair of submetacentric chromosomes with a terminal nucleolus organizer region (NOR), and another metacentric chromosome with a proximal NOR. 
Polyploidy and stressful environments

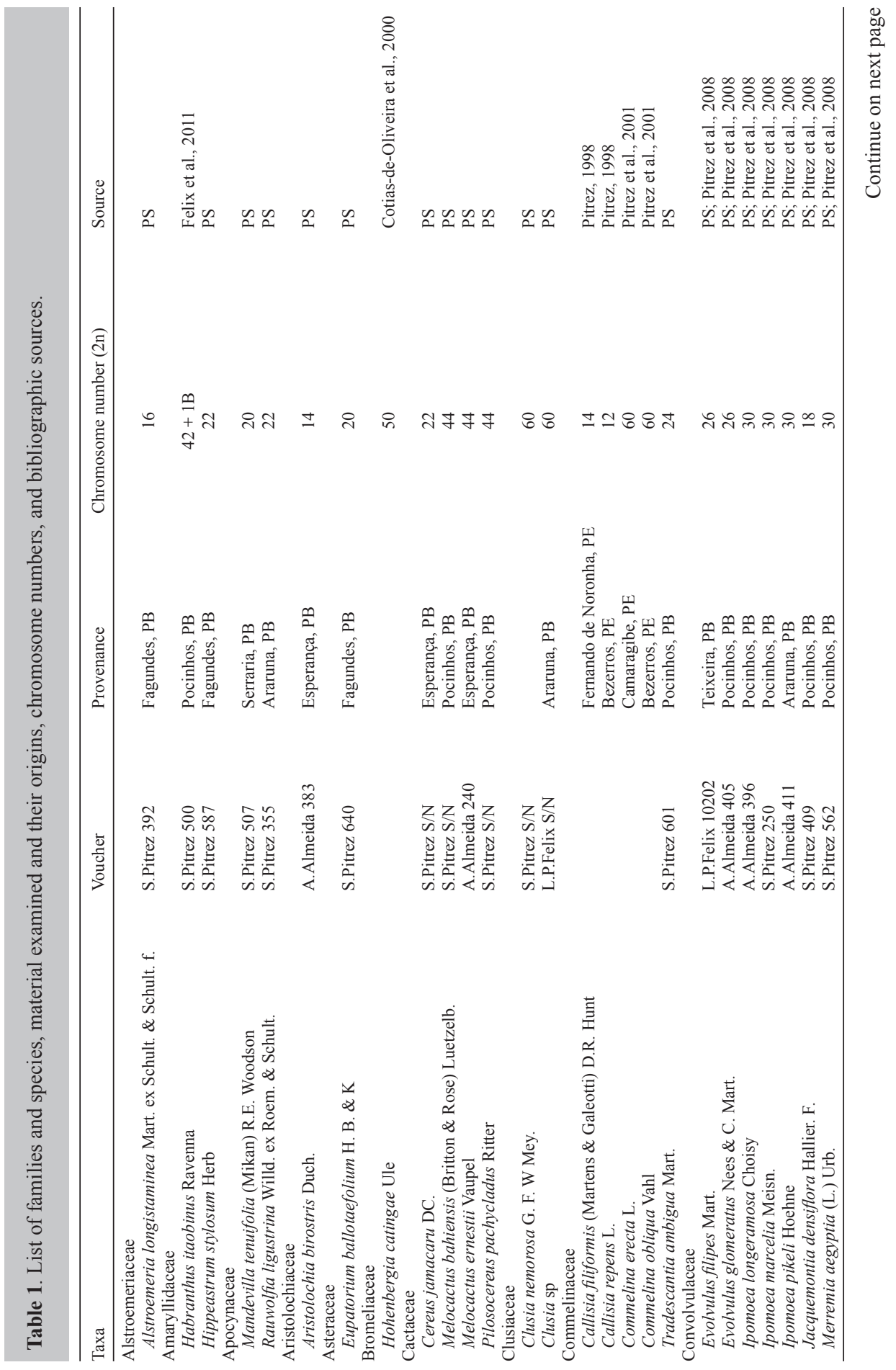


S.R. Pitrez et al.

8358

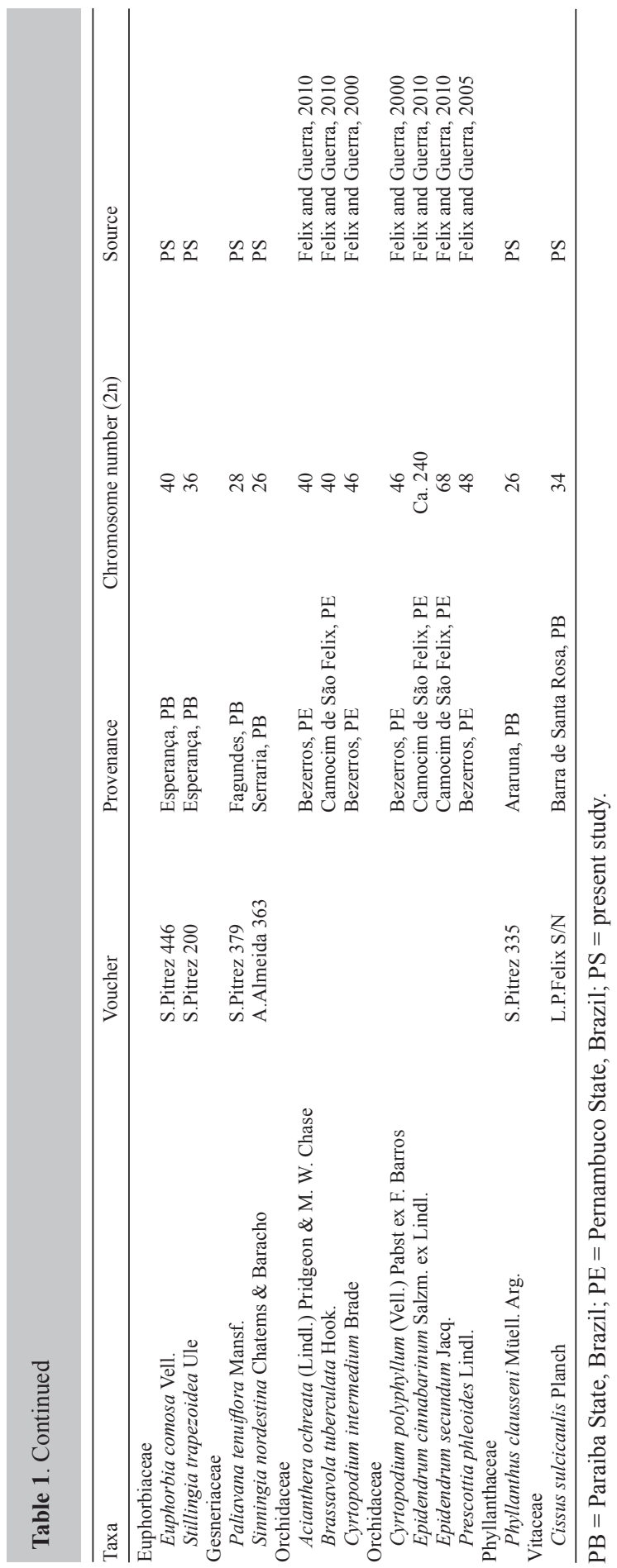




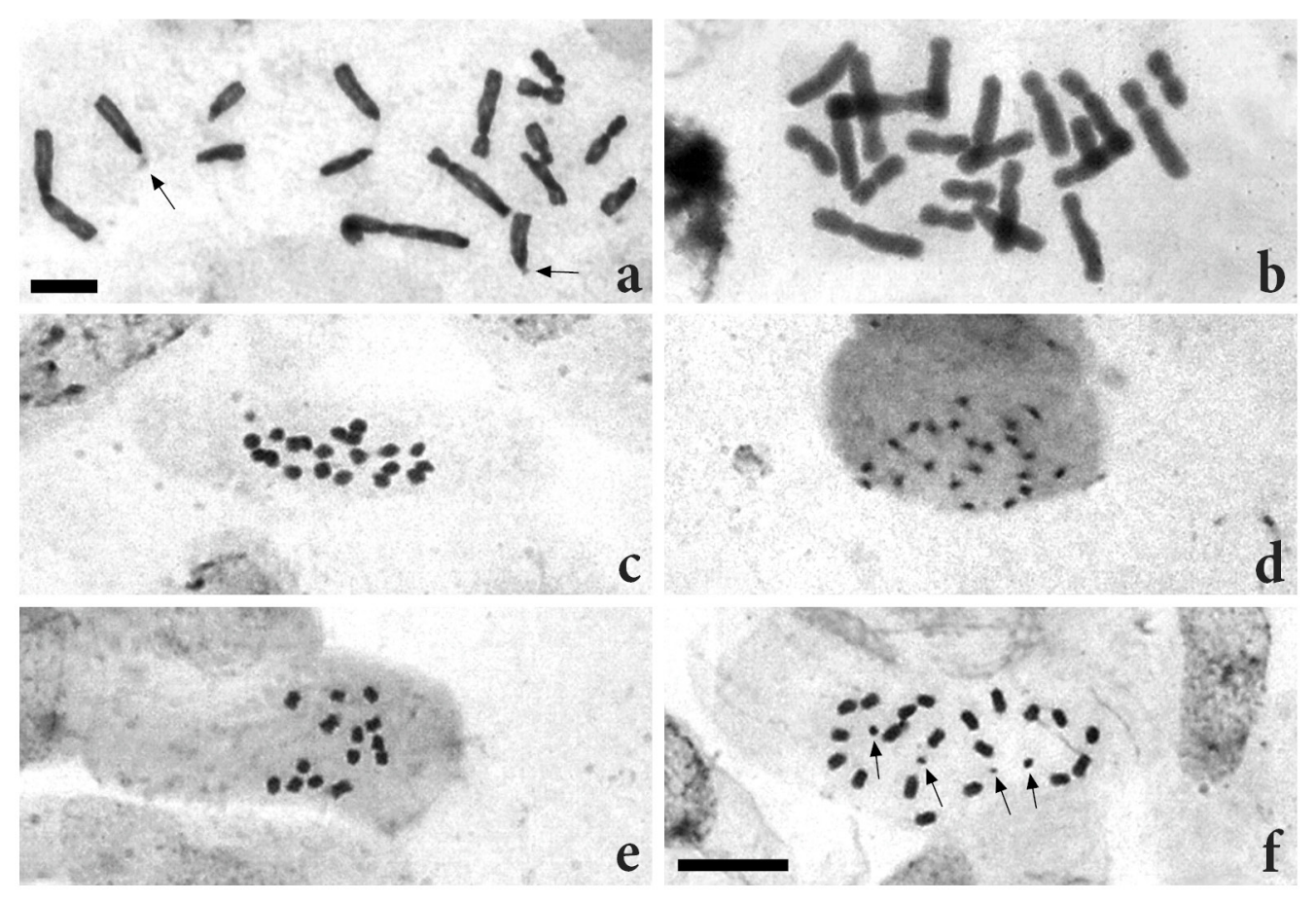

Figure 1. Chromosome complement of: a. Alstroemeria longistaminea $(2 \mathrm{n}=16) ; \mathbf{b}$. Hippeastrum stylosum $(2 \mathrm{n}$ $=22)$; . Mandevilla tenuifolia $(2 \mathrm{n}=20)$; d. Rauwolfia ligustrina $(2 \mathrm{n}=22)$; e. Aristolochia birostris $(2 \mathrm{n}=14) ; \mathbf{f}$. Eupatorium ballotaefolium $(2 \mathrm{n}=20)$. Arrows indicate satellites. Bar in $\mathrm{F}=10 \mu \mathrm{m}$.

All the species of Cactaceae examined to date demonstrated a symmetrical karyotype with metacentric and submetacentric chromosomes. Cereus jamacaru (Figure 2A) presented $2 \mathrm{n}=22$. The chromosome number $2 \mathrm{n}=44$ and chromosome lengths of 1.3 to $2.6 \mu \mathrm{m}$ that were registered here for Pilosocereus pachycladus (Figure 2B) are the first report of polyploidy for the genus. Both Melocactus bahiensis and Melocactus ernestii (Figure 2C and D) gave unique counts for the genus, $2 \mathrm{n}=44$, and had chromosome lengths ranging from 1.0 to $2.1 \mu \mathrm{m}$.

Two species of Clusiaceae were examined here: Clusia nemorosa (Figure 2E) and Clusia sp (Figure 2F), both with $2 \mathrm{n}=60$, a symmetrical karyotype, and metacentric to submetacentric chromosomes.

Tradescantia ambigua (Commelinaceae) (Figure 3A) had 2n $=24$ and a symmetrical karyotype with large metacentric chromosomes with lengths that ranged from 5.0 to $8.7 \mu \mathrm{m}$.

Within the genus Evolvulus (Convolvulaceae), Evolvulus filipis (Figure 3B), and Evolvulus glomeratus (Figure $3 \mathrm{C}$ ) demonstrated symmetrical karyotypes with $2 \mathrm{n}=26$; chromosomes were 0.8 to $1.5 \mu \mathrm{m}$ in the former and 1.3 to $2.1 \mu \mathrm{m}$ in the latter. Three species of the genus Ipomoea (I. longeramosa, I. marcellia, and I. pikeli) demonstrated $2 \mathrm{n}=30$ (Figure 3D-F), symmetrical karyotypes, metacentric to submetacentric chromosomes that were 0.3 to $1.6 \mu \mathrm{m}$, and satellites in some of the cells of all the 3 species. 
The largest chromosomes among the Convolvulaceae were observed in Jacquemontia densiflora (Figure $3 \mathrm{G}$ ), which has $2 \mathrm{n}=18$ and a symmetrical karyotype with predominantly submetacentric chromosomes that range from 2.1 to $3.8 \mu \mathrm{m}$. Merremia aegyptia (Figure $3 \mathrm{H}$ ) has $2 \mathrm{n}=30$, a symmetric karyotype with metacentric to submetacentric chromosomes measuring 1.3 to $2.3 \mu \mathrm{m}$, and a secondary terminal constriction on one of the submetacentric pairs.

Euphorbia comosa (Euphorbiaceae) is widely distributed among all of the inselbergs. It had a chromosome number of $2 \mathrm{n}=40$ (Figure 4A), and its chromosomes were 1.0 to 3.3 $\mu \mathrm{m}$. Stillingia trapezoidea had $2 \mathrm{n}=36$ (Figure 4B), large chromosomes that were 2.0 to 3.5 $\mu \mathrm{m}$, all of which were apparently acrocentric, and a secondary proximal constriction on one of the largest chromosome pairs.

Two species of the family Gesneriaceae were analyzed, Paliavana tenuiflora had $2 \mathrm{n}=$ 28 (Figure 4C), and Sinningia nordestina presented 2n =26 (Figure 4D). Both of these species demonstrated small chromosomes whose morphology was difficult to define.

Phyllanthus clausseni (Phyllanthaceae) had $2 \mathrm{n}=26$ (Figure 4E) and very small chromosomes (0.6 to $1.6 \mu \mathrm{m})$. Cissus sulcicaulis (Vitaceae) demonstrated $2 \mathrm{n}=34$ and small metacentric to submetacentric chromosomes (Figure 4F).
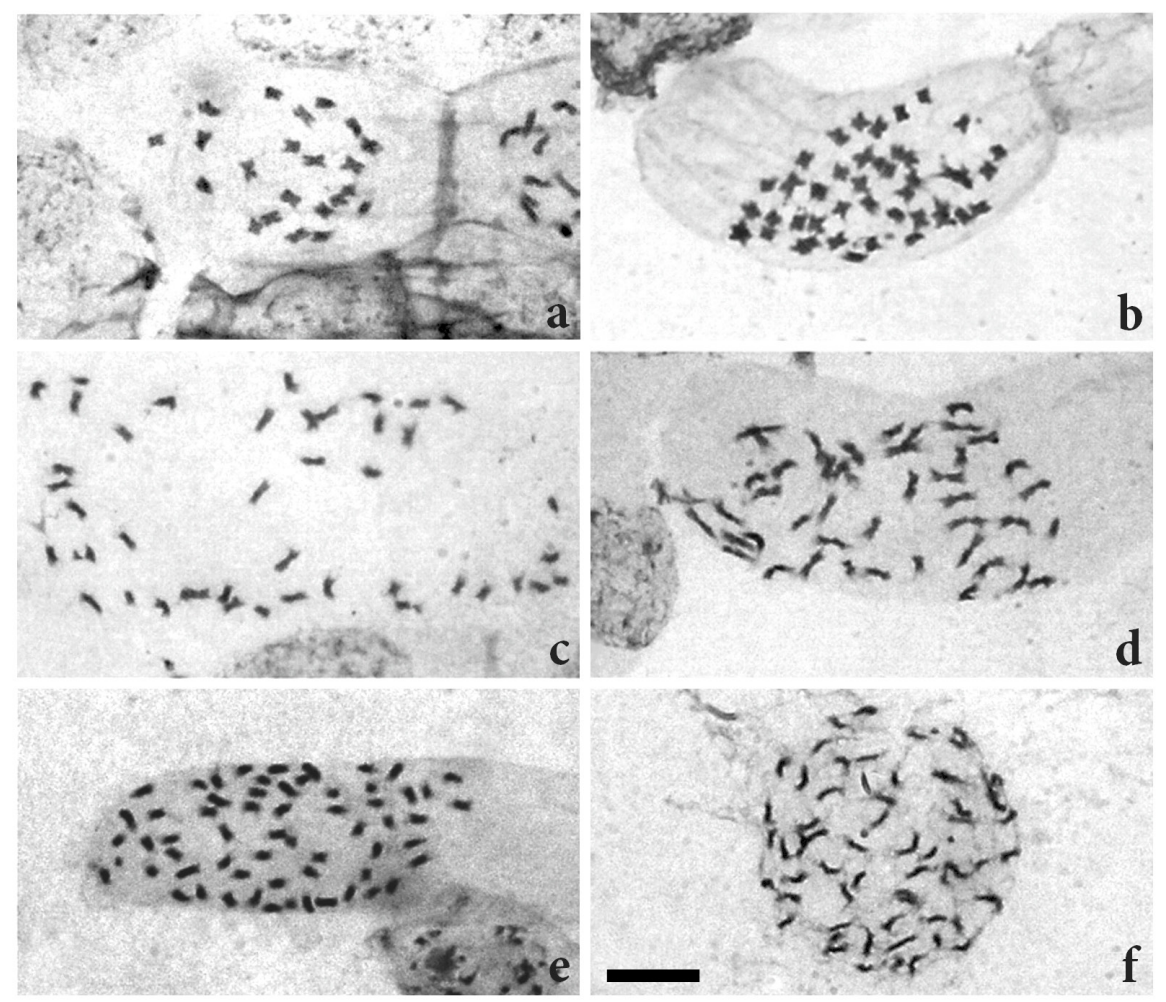

Figure 2. Chromosome complement of: a. Cereus jamacaru $(2 \mathrm{n}=22)$; b. Pilosocereus pachicladus $(2 \mathrm{n}=44)$; $\mathbf{c}$. Melocactus bahiensis $(2 \mathrm{n}=44)$; d. M. ernesti $(2 \mathrm{n}=44)$; e. Clusia nemorosa $(2 \mathrm{n}=60)$; f. Clusia $\mathrm{sp}(2 \mathrm{n}=60)$. Bar in $\mathrm{F}=10 \mu \mathrm{m}$. 


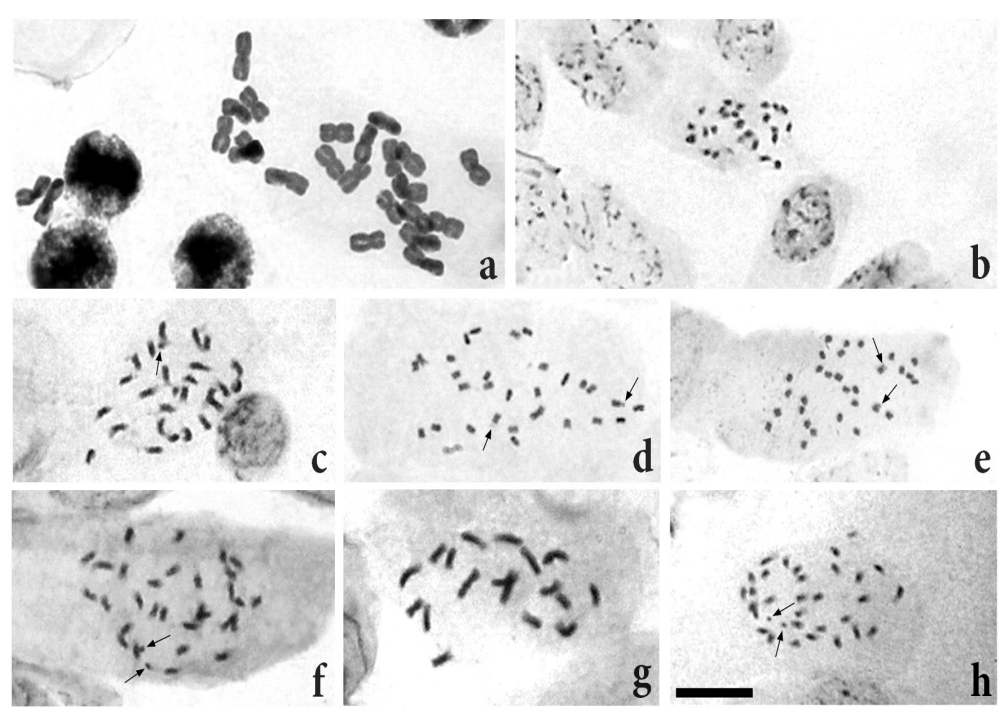

Figure 3. Chromosome complement of: a. Tradescantia ambigua $(2 \mathrm{n}=24)$; b. Evolvulus filipis $(2 \mathrm{n}=26)$; c. E. glomeratus $(2 \mathrm{n}=26)$; d. Ipomoea longeramosa $(2 \mathrm{n}=30)$; e. I. marcellia $(2 \mathrm{n}=30)$; f. I. pikeli $(2 \mathrm{n}=30)$; . Jacquemontia densiflora $(2 \mathrm{n}=18)$; h. Merremia aegyptia $(2 \mathrm{n}=30)$. Arrows indicate satellites. Bar in $\mathrm{H}=10 \mu \mathrm{m}$.
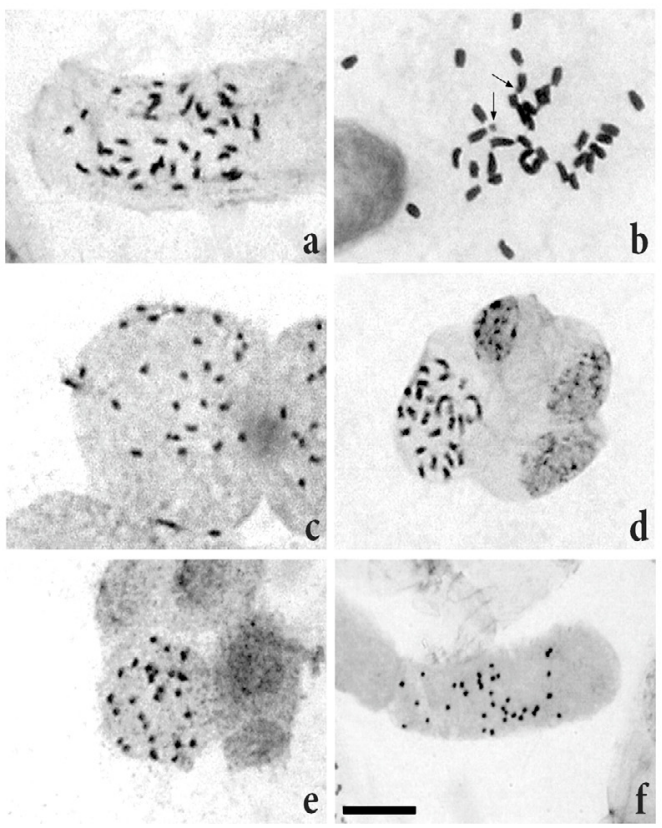

Figure 4. Chromosome complement of: a. Euphorbia comosa $(2 \mathrm{n}=40)$; b. Stillingia trapezoidea $(2 \mathrm{n}=36)$; $\mathbf{c}$. Paliavana tenuiflora $(2 \mathrm{n}=28)$; d. Sinningia nordestina $(2 \mathrm{n}=26)$; e. Phyllanthus clausseni $(2 \mathrm{n}=26)$; f. Cissus sulcicaulis $(2 \mathrm{n}=34)$. Arrows indicate satellites. Bar in $\mathrm{F}=10 \mu \mathrm{m}$. 


\section{DISCUSSION}

In addition to the 26 species that were cytogenetically investigated in this study, we included data previously published concerning 13 other species encountered on other inselbergs in northeastern Brazil and were present on the inselbergs examined here (Table 1), expanding the sample to a total of 39 species belonging to 31 genera and 15 families. There is one report of polyploidy in Commelina erecta and Commelina obliqua of the family Commelinaceae (Pitrez et al., 2001) and in Epidendrum cinnabarinum and Epidendrum secundum of the family Orchidaceae (Felix and Guerra, 2010). The single species of Bromeliaceae from the inselbergs examined here did not demonstrate different ploidy levels. Other representatives of the families Commelinaceae ( 3 species) and Orchidaceae ( 6 species) found on the inselbergs likewise did not demonstrate ploidy levels higher than those observed in related terrestrial species, except Habenaria obtusa, which had a single triploid individual (Felix and Guerra, 2005).

A wide range of chromosome numbers was observed among species of Orchidaceae on the inselbergs. Of the species in the area studied with previously published karyotypes, Brassavola tuberculata had $2 \mathrm{n}=40$, Cyrtopodium intermedium and Cyrtopodium polyphyllum had $2 \mathrm{n}=46$, Epidendrum cinnabarinum had $2 \mathrm{n}=240$, Epidendrum secundum had $2 \mathrm{n}=68, \mathrm{Ha}$ benaria obtusa had $2 \mathrm{n}=50$, Pleurothallis ochreata had $2 \mathrm{n}=40$, and Prescottia phleoides had $2 \mathrm{n}=48$ (Felix and Guerra, 2005, 2010). Of these species, Habenaria and Prescottia are typically terrestrial or rupicolous, while the other species are usually epiphytic. These chromosome numbers point to differences in ploidy levels only for Epidendrum secundum and Epidendrum cinnabarinum, while the other species are considered to be paleopolyploids that stabilized at the hexaploid level (Felix and Guerra, 2005) and are considered as diploids. Among the Bromeliaceae, the only species from the area studied that was previously analyzed did not have a chromosome number that differed from the most frequent counts for the family, independent of whether they occurred as epiphytes or in rupicolous or terrestrial environments.

The chromosome number $2 \mathrm{n}=22$ observed for Hippeastrum stylosum (Amaryllidaceae) was the same as that previously and frequently reported for this species and for others of the same genus (Dutilh, 1989). The karyotype that we observed also coincided with that previously described by Guerra (1986) for a population of the same species from Pernambuco State (also in northeastern Brazil), although those were from a terrestrial environment. Nevertheless, there is one report of polyploidy in Habranthus itaobinus (Felix, 2009), and intraspecific polyploidy was frequently observed among terrestrial species of Zephyranthes, including Zephyranthes sylvatica from Pernambuco State in northeastern Brazil (Felix et al., 2008).

Aristolochia birostris (Aristolochiaceae) with $2 \mathrm{n}=14$ is often found in terrestrial habitats. The cytogenetic analysis of this species coincides with the chromosome number that was most frequently reported for the genus (Berjano et al., 2009). A previous chromosomal analysis (Berjano et al., 2009) of material collected in terrestrial environments in the neighboring state of Pernambuco demonstrated essentially the same karyotype as the present sample.

The chromosome number of Eupatorium ballotaefolium $(2 \mathrm{n}=20)$, a weedy Asteraceae that is common on inselbergs and in other terrestrial environments, agrees with counts that are frequently associated with this genus, but it diverged from all numbers previously reported $(2 \mathrm{n}=10,30)$ for this species (Moore, 1973). Other weedy and invasive species of Asteraceae in the Caatinga vegetation of the states of Paraíba and Rio Grande do Norte likewise demonstrated variability relative to previously published chromosomal counts, possibly because of 
the existence of cryptic species. The taxonomically similar weedy species Emilia sonchifolia $(2 \mathrm{n}=10)$ and Emilia sagittata $(2 \mathrm{n}=20)$ demonstrate the same karyotype variation (Guerra and Nogueira, 1990), although it is not related to climatic stress on the inselbergs.

The chromosome number reported here for Pilosocereus pachycladus $(2 \mathrm{n}=44)$ is the first report of polyploidy for the genus, which had only one other previously published count, $2 \mathrm{n}=22$ in Pilosocereus lanuginosus (Baker, 2002). The chromosome number in Cereus jamacaru $(2 \mathrm{n}=22)$ confirmed previously published data for this species (Pedrosa et al., 1999) from a population in Pernambuco State. Cacti constitute a taxonomic group that is highly adapted to xeric environments, and they are distributed principally within the American continents. In spite of their adaptations to rigorous and dry environments, the family is predominantly diploid, with $2 n=22$. Examples of intra- and inter-specific polyploidy have been observed in numerous cacti genera, but no obvious correlations between polyploid forms and the occupation of water-stressed habitats were demonstrated. The epiphytic genera of the family, such as Rhipsalis and Phyllocladus (both epiphytic and found in humid forests) have the same $2 \mathrm{n}=22$ count that is most frequently seen in species from desert regions.

The same chromosome number presented here for Clusia nemorosa and Clusia sp (Clusiaceae) was observed in 4 other species of Clusia that were examined by Cruz et al. (1990), indicating that $x=30$ is the basic number for a majority of the species of the genus and suggesting that it is a paleopolyploid group. Numerous species of Clusia occur on inselbergs in humid environments, as terrestrial plants in humid forests and epiphytes in humid habitats (Barthlott et al., 2001), or on inselbergs in semi-arid climates, as observed in this study. There seems to be no correlation between high chromosome numbers in this group and adaptations to inselbergs or other habitats with extreme climates.

Within the family Commelinaceae, the genus Tradescantia has a basic number $x=$ 6 , with a predominance of diploid species, but it also exhibits intraspecific polyploidy, as in Tradescantia blossfeldiana, where $2 \mathrm{n}=70,90$, and 110 were observed (Jones and Jopling, 1972). However, there does not seem to be any correlation between polyploidy and rupicolous habitats in Tradescantia, and even populations of Tradescantia ambigua from non-rupicolous populations had 2n = 24 (Jones and Kenton, 1984; Pitrez et al., 2001).

The family Apocynaceae (including the Asclepiadaceae sensu APG III, 2009) is a karyologically stable group, with $2 \mathrm{n}=22$ in a large majority of the species or polyploids with $2 \mathrm{n}=44$ and 66 (Van der Laan and Arends, 1985). The present count of $2 \mathrm{n}=20$ for Maxillaria tenuifolia is the first for the genus. This species is exclusive to inselbergs and rocky field vegetation in northeastern Brazil (Watanabe et al., 2009). Chromosomal counts of $2 \mathrm{n}=20$ have been reported for other genera of Apocynaceae, such as Strophanthus and Trachelospermum, as well as $2 \mathrm{n}=18$ for Allamanda, Pachypodium, and Prestonia (Van der Laan and Arends, 1985). Counts of $2 n=20$ and 22 in the 2 species examined here is within the modal range (or near the mode number) for the family, and apparently they are diploids.

The karyotypes for the 3 species of the genus Ipomoea (Convolvulaceae) that were analyzed here are in agreement with previous reports $(2 n=30)$, including the occurrence of secondary constrictions in other species of the genus (Sinha and Sharma, 1992). Within the genus Evolvulus, Evolvulus filipis and Evolvulus glomeratus, both with $2 \mathrm{n}=26$, were previously analyzed by Pitrez et al. (2008), and this chromosome number was reported for other species of this genus (Goldblatt and Johnson, 1990). The chromosome numbers observed in Merremia aegyptia $(2 \mathrm{n}=30)$ confirmed previously published counts (Vij et al., 1974). However, 
the observations of Elias (1967), who reported 2n $=28$ for Merremia aegyptia and Merremia umbellata, were not confirmed by our observations. A more detailed discussion of the taxonomic implications and the karyotype evolution of the family Convolvulaceae were published by Pitrez et al. (2008). Overall, the chromosome numbers that were observed for species of Convolvulaceae growing on inselbergs in Paraiba do not significantly differ from those cited in the literature or from those attributed to other terrestrial species of the family. In general, the genera are karyologically stable, and their composite species do not demonstrate large variations in terms of their intra- or interspecific chromosome numbers.

Euphorbia and Phyllanthus (Euphorbiaceae) demonstrated wide numerical variations. Analyses of 18 species of Phyllanthus growing in the United States and in Central America yielded chromosome numbers that varied between $n=8$ and $n=78$ (Webster and Ellis, 1962), without any obvious correlation with habitat. Polyploid variation in Euphorbia (ranging from $2 \mathrm{n}=18$ to $2 \mathrm{n}=44$ ) was reduced among species growing on the Macaronesian Islands (Molero et al., 2002). In this case, the polyploid species were in the plesiomorphic state, while the diploids (with cactus-like growth habits adapted to environments under water stress) were the most derived. The basic numbers $x=13$ for Phyllanthus and $x=10$ for Euphorbia were confirmed in our survey. Stillingia is the least studied of the 3 genera, with only 3 published counts of $2 n=22$ (in 2 reports) and $2 n=36$ (in another) (Goldblatt and Johnson, 1990), partially coinciding with our data.

For the family Gesneriaceae, no previously published data is known for Paliavana, but a previous report of $2 n=26$ was found for Sinningia incarnata (Goldblatt, 1984). Approximately 560 of the 2500 known species of the family Gesneriaceae are epiphytes (Benzing, 1990). In Brazil, the genera Sinningia and Paliavana are predominantly rupicolous (Souza and Lorenzi, 2005), without any apparent correlation between polyploidy and adaptations to a saxicolous habitat.

Cissus sulcicaulis (Vitaceae) is frequently encountered on rock outcrops in northeastern Brazil and in terrestrial habitats in the Caatinga drylands. Although the genus Cissus demonstrates numerous chromosomal variations from $2 n=22$ to 96 (Moore, 1973; Goldblatt, 1984 ), the $2 n=34$ number cited here is unique for the genus.

Of a total of 39 angiosperm species that occur on 5 inselbergs in Paraíba State, a majority were diploids, not differing from previous chromosome records for the same species that occur in other types of habitats. Even paleopolyploid groups, such as the families Orchidaceae and Bromeliaceae demonstrated predominantly diploid cytotypes (Felix and Guerra, 2005). Groups with high levels of ploidy, such as the genera Melocactus (Cactaceae), Clusia (Clusiaceae), and Epidendrum (Orchidaceae), seem to be individual cases and are independent of the environmental stress assumed to be associated with inselberg habitats. In fact, for plants in areas where nutrient levels are limited, there will be selection against polyploids or for those that cannot eliminate excess DNA (Leitch and Leitch, 2008), probably because polyploidy increases demands for the production of more proteins and nucleic acids. The occurrence of these polyploid species in the inselbergs studied may be related to the efficient ability to use water. As such, this study does not support the hypothesis that polyploid species tend to occur in rupicolous habitats and, by extension, other habitats having rigorous environments.

\section{ACKNOWLEDGMENTS}

Research supported by Conselho Nacional de Desenvolvimento Científico e Tec- 
nológico (CNPq) and Instituto Nacional do Semiárido (INSA).

\section{REFERENCES}

Ainouche ML and Jenczewski E (2010). Focus on polyploidy. New Phytol. 186: 1-4.

APG III (2009). An update of the Angiosperm Phylogeny Group classification for the orders and families of flowering plants: APG III. Bot. J. Linn. Soc. 161: 105-121.

Baker MA (2002). Chromosome numbers and their significance in some Opuntioideae and Cactoideae (Cactaceae) of mainland Ecuador and Peru. Haseltonia 9: 69-77.

Barthlott W, Schmit-Neuerburg V, Nieder J and Engwald S (2001). Diversity and abundance of vascular epiphytes: a comparison of secondary vegetation and primary montane rain forest in the Venezuelan Andes. Plant Ecol. 152: 145-156.

Benzing DH (1990). Vascular Epiphytes. Cambridge University, New York.

Berjano R, Roa F, Talavera S and Guerra M (2009). Cytotaxonomy of diploid and polyploid Aristolochia (Aristolochiaceae) species based on the distribution of CMA/DAPI bands and 5S and 45S rDNA sites. Plant Syst. Evol. 280: 219-227.

Cotias-de-Oliveira ALP, Assis JGA, Bellintani MC, Erade JCS, et al. (2000). Chromosome numbers in Bromeliaceae. Genet. Mol. Biol. 23: 173-177.

Cruz ND, Boaventura YMS and Sellito YM (1990). Cytological studies of some species of the genus Clusia L. (Guttiferae). Rev. Bras. Genet. 13: 335-345.

Dutilh JHA (1989). Morphological variation in a population of Hippeastrum Herb. Herbertia 45: 152-155.

Ehrendorfer F (1970). Chromosomen, verwandtschaft und evolution tropischer holzpflanzen. I. Allgemeine hinweise. Österr. Bot. Z. 118: 30-37.

Elias TS (1967). Chromosome numbers of phanerogams 2. Ann. Missouri Bot. Gard. 54: 178-181.

Felix LP and Guerra M (2000). Cytogenetics and cytotaxonomy of some Brazilian species of Cymbidioid orchids. Genet. Mol. Biol. 23: 957-97.

Felix LP and Guerra M (2005). Basic chromosome numbers of terrestrial orchids. Plant Syst. Evol. 254: 131-148.

Felix LP and Guerra M (2010). Variation in chromosome number and the basic number of subfamily Epidendroideae (Orchidaceae). Bot. J. Linn. Soc. 163: 234-278.

Felix WJP (2009). Caracterização citogenética em espécies do gênero Zephyranthes Herb. (Amaryllidaceae). Master's thesis, Universidade Federal Rural de Pernambuco, Recife.

Felix WJP, Dutilh JHA, Melo NF, Fernandes AA, et al. (2008). Intrapopulational chromosome number variation in Zephyranthes sylvatica Baker (Amaryllidaceae: Hippeastreae) from northeast Brazil. Rev. Bras. Bot. 31: 371-375.

Felix WJP, Felix LP, Melo NF, Oliveira MBM, et al. (2011). Karyotype variability in species of the genus Zephyranthes Herb. (Amaryllidaceae-Hippeastreae). Plant Syst. Evol. 294: 263-271.

Goldblatt P (1984). Index to Plant Chromosome Numbers 1979-1981. Missouri Botanical Garden Press, St. Louis.

Goldblatt P and Johnson DE (1990). Index to Plant Chromosome Numbers 1986-1987. Missouri Botanical Garden Press, St. Louis.

Guerra M (1986). Citogenética de angiospermas coletadas em Pernambuco I. Rev. Bras. Genet. 9: 21-40.

Guerra M (2012). Cytotaxonomy: the end of childhood. Plant Biosyst. 146: 703-710.

Guerra M and Nogueira MTM (1990). The cytotaxonomy of Emilia spp. (Asteraceae: Senecioneae) occurring in Brazil. Plant Syst. Evol. 170: 229-236.

Jones K and Jopling C (1972). Chromosomes and the classification of the Commelinaceae. Bot. J. Linn. Soc. 65: 129-162.

Jones K and Kenton A (1984). Mechanisms of Chromosome Change in the Evolution of the Tribe Tradescantieae (Commelinaceae). Vol. II. In: Chromosomes in Evolution of Eukaryotic Groups (Sharma AK and Sharma A, eds.). CRC Press, Boca Raton, 143-168.

Leitch AR and Leitch IJ (2008). Genomic plasticity and the diversity of polyploid plants. Science 320: 481-483.

McIntyre PJ (2012). Polyploidy associated with altered and broader ecological niches in the Claytonia perfoliata (Portulacaceae) species complex. Am. J. Bot. 99: 655-662.

Molero J, Garnatje T, Rovira A, Garcia-Jacas N, et al. (2002). Karyological evolution and molecular phylogeny in Macaronesian dendroid spurges (Euphorbia subsect. Pachycladae). Plant Syst. Evol. 231: 109-132.

Moore RJ (1973). Index to plant chromosome numbers 1967-1971. Regnum Veg. 90: 1-539.

Parmentier I, Stévart T and Hardy OJ (2005). The inselberg flora of Atlantic Central Africa. I. Determinants of species assemblages. J. Biogeogr. 32: 685-696.

Pedrosa A, Gitaí J, Silva AEB, Felix LP, et al. (1999). Citogenética de angiospermas coletadas em Pernambuco - V. Acta Bot. Bras. 13: 49-60.

Genetics and Molecular Research 13 (4): 8353-8366 (2014)

CFUNPEC-RP www.funpecrp.com.br 
Pitrez SR (1998). Números cromossômicos de Commelinaceae no Nordeste do Brasil. Master's thesis, Universidade Federal de Recife, Recife.

Pitrez SR (2006). Florística, fitossociologia e citogenética de angiospermas ocorrentes em inselbergues. Doctoral thesis, Universidade Federal da Paraíba, Areia.

Pitrez SR, Felix LP, Barreto R and Guerra M (2001). Números cromossômicos de espécies de Commelinaceae R. Br. ocorrentes no nordeste do Brasil. Bol. Bot. Univ. São Paulo 19: 7-14.

Pitrez SR, Andrade LA, Alves LIF and Felix LP (2008). Karyology of some Convolvulaceae species occurring in NE Brazil inselbergs. Plant Syst. Evol. 276: 235-241.

Ramsey J and Schemske DW (2002). Neopolyploidy in flowering plants. Annu. Rev. Ecol. Syst. 33: 589-639.

Sarthou C, Larpin D, Fonty E, Pavoine S, et al. (2010). Stability of plant communities along a tropical inselberg ecotone in French Guiana (South America). Flora 205: 682-694.

Sinha S and Sharma SN (1992). Taxonomic significance of karyomorphology in Ipomoea spp. Cytologia 57: 289-293.

Soltis DE, Soltis PS and Tate JA (2004). Advances in the study of polyploidy since plant speciation. New Phytol. 161: 173-191.

Souza VC and Lorenzi H (2005). Botânica Sistemática: Guia Ilustrado para Identificação das Famílias de Angiospermas da Flora Brasileira, Baseado em APG II. Instituto Plantarum, São Paulo.

Van der Laan FN and Arends JC (1985). Cytotaxonomy of the Apocynaceae. Genetica 68: 3-35.

Vij SP, Singh S and Sachdeva VP (1974). In IOPB chromosome number reports XLV. Taxon 23: 619-624.

Watanabe Y, Takahashi A, Itoh M and Takano-Shimizu T (2009). Molecular spectrum of spontaneous de novo mutations in male and female germline cells of Drosophila melanogaster. Genetics 181: 1035-1043.

Webster GL and Ellis JR (1962). Cytotaxonomic studies in the Euphorbiaceae, subtribe Phyllanthinae. Am. J. Bot. 49: 14-18. 